\title{
Path Analysis (Analisis Jalur) : Pengaruh Quality Work Life Terhadap Employee Engagement Dan Turnover Intention Perawat Rumah Sakit
}

\section{Doby Indrawan}

Departemen Bioetika, IKM dan Pendidikan Kedokteran, Fakultas Kedokteran dan Ilmu Kesehatan, Universitas Islam Negeri Maulana Malik Ibrahim Malang

\begin{tabular}{l} 
Keyword: \\
Quality work life; \\
employee \\
engagement; \\
turnover intention \\
\hline
\end{tabular}

\begin{tabular}{l} 
Abstract \\
\hline Background: Turnover happens in almost all aspects of organisations, \\
including in medical aspect. Turnover of the hospital nurses has direct \\
impacts to the service quality because nurses are the spearhead of the \\
hospital services. Turnover could be predicted from the amount of turnover \\
intention that is influenced by several factors i.e. quality work life and \\
employee engagement. Objective: to prove the influence of quality work life \\
to employee engagement and turnover intention of the hospital nurses. \\
Method: The data is collected by using the questionnaires that is given to 35 \\
nurses of Ananda Hospital. The data is analyzed by path analyses. Result: \\
there is influence qualitywork life to employee engagement and employee \\
engagement towards turnover intention. Conclucion: there is an effect of \\
quality work life to turnover intention through employee engagement. \\
$\boldsymbol{A B S} \boldsymbol{B} \boldsymbol{T} \boldsymbol{R} \boldsymbol{A} \boldsymbol{K}$
\end{tabular}

Kata kunci : ABSTRAK

Quality work life; $\quad$ Latar belakang: Turnover terjadi di semua bidang organisasi, tidak employe;

engagement;

turnover intention terkecuali di bidang kesehatan. Turnover perawat di rumah sakit berdampak langsung pada kualitas layanan karena perawat merupakan ujung tombak pelayanan. Turnover dapat diprediksi dari besarnya turnover intention yang dipengaruhi oleh beberapa faktor diantaranya quality work life dan employee engagement.Tujuan: mengetahui pengaruh quality work life terhadap employee engagement dan turnover intention perawat di rumah sakit. Metode: Data dikumpulkan menggunakan kuesioner yang dibagikan pada 35 responden di Rumah Sakit Ananda. Data dianalisis menggunakan analisis jalur. Has il: studi menunjukkan terdapat pengaruh quality work life terhadap employee engagement dan employee engagement terhadap turnover intention. Kesimpulan: ada pengaruh quality work life terhadap turnover intention melalui employee engagement.

*Corresponding author

Email: dobyindrawan@kedokteran.uin-malang.ac.id 


\section{PENDAHULUAN}

Turnover perawat menjadi masalah di seluruh dunia meskipun pada tingkat yang berbeda. Survei yang dilakukan oleh American Organization of Nurse Executive (AONE) menunjukan tingkat turnover rata-rata nasional di Amerika pada tahun 2000 adalah sebesar 21,3\% [1]. Turnover perawat menyebabkan kekurangan perawat di beberapa negara di dunia, diantaranya adalah negara berkembang. Beberapa negara Afrika Tengah, Liberia dan Uganda masih mengalami kekurangan perawat bila dibandingkan dengan jumlah penduduk yakni kurang dari 10 perawat per 100.000 orang penduduk [2]. Kondisi ini berbeda dengan keadaan di negara maju seperti Norwegia, Finlandia dan Australia yakni 1.000 orang perawat per 100.000 penduduk [3].

Di Indonesia, jumlah perawat masih tertinggal dibandingkan negaranegara ASEAN seperti Malaysia. Rasio perawat terhadap penduduk di Indonesia tahun 2019 adalah 10:10.000 artinya 1 perawat untuk 1000 penduduk. Sedangkan rasio perawat terhadap penduduk di Malaysia pada tahun 2019 adalah 18:10.000. Rasio ideal jumlah perawat terhadap penduduk di Indonesia tahun 2019 seharusnya adalah $18: 10.000$ [4].

Kondisi kurangnya perawat di perburuk dengan adanya angka turnover yang tinggi di rumah sakit pada beberapa daerah di Indonesia. Hasil penelitian beberapa rumah sakit di Medan mengalami angka turnover yang tinggi yaitu sekitar $25 \%$ hingga 34\% [5]. Penelitian lainnya menunjukan bahwa di salah satu rumah sakit di Batam mengalami turnover sebesar $13 \%$ dan 23\% pada tahun 2005-2006 [6]. Salah satu rumah sakit di Jawa Timur juga mengalami angka turnover yang tinggi yaitu 32\% tahun 2010 meskipun pada tahun 2013 telah menurun menjadi 16\% [7]. Angka turnover ini lebih tinggi bila dibandingkan dengan angka turnover yang ideal, yaitu 5-10\% per tahun [8].
Rumah Sakit Ananda, rumah sakit yang digunakan dalam penelitian ini, mengalami angka turnover yang fluktuatif, yaitu $14 \%$ tahun 2011, 12\% tahun 2012, 12\% tahun 2013 dan $13 \%$ pada tahun 2014 [7]. Angka-angka tersebut menunjukan bahwa selama beberapa tahun terakhir (2012-2014) Rumah Sakit Ananda mengalami angka turnover terus meningkat yang berakibat menurunnya jumlah perawat sehingga dapat berdampak penurunan kualitas pelayanan.

Hasil wawancara tidak terstruktur pada studi pendahuluan yang dilakukan pada beberapa perawat dan staf di Rumah Sakit Ananda didapatkan bahwa alasan perawat keluar disebabkan antara lain adalah karena ketidakpuasan perawat terhadap pendapatan yang diterima, tingginya beban kerja perawat dan beberapa perawat diterima sebagai pegawai negeri sipil (PNS).

Penyebab turnover ini hampir serupa dengan penelitian Hayati pada tahun 2007, pada penelitian ini dinyatakan bahwa tingginya angka turnover disebabkan oleh kehidupan kerja penuh tekanan (stress at work), kompensasi kurang, regulasi tidak jelas, kurang adanya penghargaan dan tidak ada jaminan masa depan [6]. Perpindahan perawat menjadi PNS di rumah sakit pemerintah dapat diartikan bahwa perawat Rumah Sakit Ananda masih mencari tempat kerja yang memberikan job security yang kuat, selain budaya di Indonesia bahwa menjadi PNS menunjukan kebanggaan [9]. Job insecurity merupakan salah satu penyebab intention to leave [10]. Turnover perawat di rumah sakit dapat diprediksi dari besarnya turnover intention yang dimiliki oleh seorang perawat di rumah sakit. Sebuah literatur menyatakan bahwa terdapat hubungan yang kuat antara turnover dengan turnover intention, sehingga turnover intention dapat digunakan untuk memprediksi turnover [11]. 
Padahal, perawat merupakan ujung tombak pelayanan yang secara langsung berinteraksi dan terpapar dalam waktu yang lama dengan pasien. Jika terjadi kekurangan jumlah perawat karena turnover, maka akan berdampak seperti pekerjaan menjadi lebih sulit, beban kerja staf yang ditinggalkan meningkat, lalu timbul stres kerja, sehingga berdampak pada kualitas perawatan yang diberikan [6]. Turnover yang tinggi juga mengakibatkan operasional rumah sakit menjadi tidak efektif karena rumah sakit kehilangan perawat yang berpengalaman dan perlu melatih kembali perawat yang baru [12].

Sebuah studi di China menyatakan dalam penelitiannya bahwa quality work life, job embeddedness dan affective commitment mempengaruhi turnover intention. Studi ini dilakukan pada perawat di salah satu rumah sakit di China, hasilnya menunjukan bahwa quality work life (QWL) yang tinggi akan meningkatkan job embeddedness dan affective commitment sehingga menurunkan turnover intention [13]. Studi lain menyatakan bahwa kualitas kehidupan kerja (quality work life) merupakan bagian dari kualitas hidup (quality of life) yang dipengaruhi oleh pekerjaannya, dalam arti yang lebih luas bahwa quality work life adalah cara seorang karyawan mengevaluasi pekerjaan dalam kehidupannya [14]. Quality work life dipengaruhi oleh kepuasaan seseorang terhadap pekerjaannya, kehidupan keluarga, kegiatan rekreasi, kehidupan sosial, status keuangan, termasuk juga lingkungan kerja seperti; kehidupan nonkerja, kehidupan secara keseluruhan, kebahagian pribadi dan kesejahteraan yang sifatnya pribadi [15].

Penelitian lain menyatakan bahwa kualitas kehidupan kerja (quality work life), kepuasan kerja dan kelelahan emosi yang dialami perawat karena beban kerjanya menyebabkan meningkatnya keinginan untuk keluar dari pekerjaan (turnover intention) [16]. Beberapa penelitian lainya seperti Huang et al., (2007), Almalki et al., (2012) dan Lee et al., (2013) menunjukkan hal yang sama bahwa quality work life (QWL) dapat mempengaruhi turnover intention (TOI).

Selain quality work life (QWL), penelitian lain oleh Ang et al., (2013), Putri (2013) dan Takawira et al., (2014) menunjukan adanya faktor yang berbeda yang mempengaruhi employee engagement. Mereka menyatakan bahwa employee engagement secara signifikan berpengaruh terhadap turnover intention. Employee engagement [23] disebut juga job engagement [24] atau work engagement [25]. Employee engagement (keterikatan) menurut Kahn (1990) adalah ketika seseorang melibatkan diri, mereka membawa semua aspek dalam diri mereka baik secara kognitif, emosional dan fisik saat bekerja. Employee engagement secara psikologis muncul ketika seorang karyawan menjalankan dan memenuhi perannya sebagai seorang karyawan dalam sebuah organisasi [23] dan [26].

Work engagement merupakan sebuah perasaan positif dan memotivasi kinerja yang berhubungan dengan keadaan yang ditandai dengan semangat, dedikasi dan absorpsi [27]. Semangat mengacu pada energi yang kuat dan ketahanan mental saat bekerja [27]. Dedikasi mengacu pada rasa kebermaknaan, antusiasme, inspirasi, kebanggaan terhadap organisasi dan tertantang oleh pekerjaan [27]. Absorpsi ditandai dengan sepenuhnya terkonsentrasi dan merasa senang dalam mengerjakan sebuah pekerjaan, sehingga merasa bahwa waktu berlalu dengan cepat dan terkadang kesulitan untuk memisahkan diri dari pekerjaan [27]. Penelitian Kanten dan Sadullah (2012) menunjukkan quality work life (QWL) mempengaruhi work engagement. Dalam penelitiannya disimpulkan bahwa terdapat hubungan yang signifikan antara quality work life terhadap work engagement dan terdapat perbedaan persepsi antara karyawan pada level atas dan bawah terhadap quality work 
life serta terdapat perbedaan tingkat work engagement pada karyawan level atas dengan karyawan level bawah.

Berdasarkan latar belakang tersebut, peneliti melakukan penelitian untuk mengetahui pengaruh quality work life terhadap employee engagement dan turnover intention perawat di Rumah Sakit Ananda.

\section{METODE PENELITIAN}

Penelitian ini dilakukan dengan survei analitik menggunakan pendekatan cross sectional, suatu teknik penelitian yang menekankan waktu pengukuran/observasi data variabel bebas dan tergantung hanya satu kali pada satu saat [29]. Populasi dari penelitian ini adalah seluruh perawat yang berkerja di Rumah Sakit Ananda, penelitian ini dilakukan dalam kurun waktu satu bulan. Teknik pengambilan sampel yang digunakan dalam penelitian ini yaitu teknik non-probability sampling tipe purposive sampling dengan jumlah sampel sebanyak 35 responden. Responden terdiri dari perawat wanita dan laki-laki. Variabel yang digunakan dalam penelitian ini terdiri dari tiga variabel yaitu quality work life, turnover intention, dan employee engagement. Penelitian ini menggunakan kuesioner sebagai instrumen pengumpulan data. Kuesioner ini terdiri dari pertanyaan tertutup untuk mengukur quality work life, employee engagement dan turnover intention yang berisi 34 pertanyaan.

Pengumpulan data dilakukan secara langsung dengan cara memberikan kuesioner yang telah disusun untuk diisi oleh responden. Peneliti menjelaskan terlebih dahulu latar belakang, tujuan penelitian, dan manfaat penelitian kepada responden melalui lembar PSP (Penjelasan Sebelum Persetujuan). Responden yang setuju mengikuti penelitian kemudian diminta untuk menandatangani informed consent. Data pada penelitian ini dianalisis dengan menggunakan analisis jalur (Path Analysis), metode untuk mempelajari pengaruh langsung dan tak langsung diantara variabel-variabel bebas dan variabel-variabel terikat. Tujuan dari path analysis adalah menentukan besar pengaruh langsung dan tidak langsung dari sejumlah variabel berdasarkan koefisien regresi beta (koefisien path). Path analysis bukan metode untuk menemukan penyebab, namun untuk menguji kebenaran kausal yang telah diteorikan. Path analysis dapat menghasilkan kesimpulan tentang variabel mana yang memiliki pengaruh kuat terhadap variabel terikat. Analisis data pada penelitian ini menggunakan software SPSS for Windows ver. 24

\section{HASIL DAN PEMBAHASAN Hasil}

Responden pada penelitian ini adalah seluruh perawat baik berstatus karyawan tetap, karyawan kontrak maupun karyawan yang sedang menjalani masa orientasi yang berjumlah total sebanyak 35 orang dengan masa kerja minimal 1 bulan. Data rincian responden berdasarkan kualifikasi pendidikan dan status kepegawaian disajikan pada tabel 1 .

Tabel 1 menunjukan bahwa sebagian besar responden memiliki jenjang pendidikan Diploma 3 Keperawatan dan status kepegawaian paling banyak adalah karyawan kontrak. Karakteristik responden berdasarkan usia, jenis kelamin, status perkawinan, masa kerja dan pendidikan terakhir disajikan pada tabel 2 .

Tabel 2 menunjukan bahwa responden terbanyak $(80 \%)$ berada dalam rentang usia 20 tahun sampai 29 tahun. Sebagian besar responden $(70 \%)$ adalah perawat perempuan dengan perbandingan jumlah yang sudah menikah hampir sama dengan yang masih lajang. Masa kerja responden terbanyak (86\%) kurang dari 5 tahun, bahkan $52 \%$ diantaranya masih mempunyai masa kerja kurang dari 1 tahun dengan pendidikan terakhir terbanyak adalah D3 Keperawatan sebesar $89 \%$. Gambaran responden ini 
menggambarkan bahwa secara keseluruhan perawat RS Ananda ini masih cukup muda dan relatif baru bekerja.

Variabel quality work life (X) terdiri dari indikator job and career satisfaction (kepuasan kerja dan karir), control at work (kontrol dalam pekerjaan), home-work interface (hubungan pekerjaankeluarga), general well-being (kesejahteraan secara umum), stress at work (tekanan dalam pekerjaan) dan working conditions (kondisi pekerjaan). Hasil tabulasi distribusi frekuensi variabel quality work life $(\mathrm{X})$ disajikan pada tabel 3.

Tabel 1. Karakteristik status kepegawaian responden

\begin{tabular}{lccccc}
\hline No & Kualifikasi Pendidikan & Tetap & Kontrak & Orientasi & Total \\
\hline 1 & Sarjana Keperawatan & 1 & 3 & - & 4 \\
2 & D-4 Keperawatan & - & - & - & - \\
3 & D-3 Keperawatan/Akper & 7 & 16 & 8 & 31 \\
\hline & Jumlah & 8 & 19 & 8 & 35 \\
\hline
\end{tabular}

Tabel 2. Karakteristik responden

\begin{tabular}{llcc}
\hline & Variabel & Jumlah (n) & Persentase \\
\hline \multirow{2}{*}{ Usia } & $20-29$ tahun & 28 & $80 \%$ \\
& $30-39$ tahun & 6 & $17 \%$ \\
& $40-49$ tahun & 1 & $3 \%$ \\
\hline \multirow{2}{*}{ Jenis kelamin } & Laki-laki & 10 & $30 \%$ \\
& Perempuan & 25 & $70 \%$ \\
\hline \multirow{2}{*}{ Status perkawinan } & Menikah & 18 & $51 \%$ \\
& Belum menikah & 17 & $49 \%$ \\
\hline \multirow{2}{*}{ Masa kerja } & $<1$ tahun & 18 & $52 \%$ \\
& $1-5$ tahun & 12 & $34 \%$ \\
\multirow{2}{*}{ Pendidikan Terakhir } & $>5$ tahun & 5 & $14 \%$ \\
& S1 Keperawatan & 4 & $11 \%$ \\
& D3 Keperawatan & 31 & $89 \%$ \\
\hline
\end{tabular}

Tabel 3. menunjukan pendapat responden pada aspek quality work life di RS Ananda. Hampir seluruh responden (lebih dari 90\%) menyatakan setuju dan sangat setuju pada tiga item, yaitu kesempatan responden dalam pengembangan karir (94\%), responden termotivasi untuk meningkatkan kemampuannya (97\%) dan kesempatan dalam menyampaikan pendapat $(92 \%)$. Tidak ada responden yang menyatakan sangat tidak setuju pada seluruh item variabel quality work life, namun masih ada responden menyatakan tidak setuju dan ragu-ragu lebih dari $50 \%$ pada beberapa item, yaitu keterlibatan responden dalam pengambilan keputusan (55\%) dan pemberian fasilitas penunjang oleh Rumah Sakit Ananda (57\%).
Indikator job and career satisfaction (kepuasan kerja dan karir) memiliki rerata tertinggi pada variabel quality work life (X) yakni sebesar 4.10. Hal ini berarti job and career satisfaction (kepuasan terhadap pekerjaan dan karir) merupakan indikator pada variabel quality work life perawat Rumah Sakit Ananda yang dinilai paling tinggi oleh responden. Rerata indikator job and career satisfaction (kepuasan kerja dan karir) dihasilkan dari dua item dengan rerata item yang hampir sama, yaitu kesempatan responden dalam pengembangan karir (4.09) dan responden termotivasi untuk meningkatkan kemampuannya (4.11).

Indikator yang memiliki rerata terendah ditunjukkan oleh control at work (kontrol dalam pekerjaan) sebesar 3.48 dan working conditions (kondisi kerja) sebesar 
3.53 meskipun keduanya masuk dalam kategori sedang (antara 2.34-3.67). Ada dua item dengan rerata terendah dari kedua indikator tersebut, yaitu keterlibatan responden dalam pengambilan keputusan (rerata 3,31) dan pemberian fasilitas penunjang oleh Rumah Sakit Ananda (rerata 3,34). Hal ini dapat diartikan bahwa $35 \%$ perawat merasa ragu dan tidak setuju bahwa mereka dilibatkan dalam pengambilankeputusan. Selain itu, cukup banyak perawat (57\%) yang menyatakan ragu-ragu bahkan tidak setuju bahwa Rumah Sakit Ananda sudah memberikan fasilitas penunjang. Meskipun demikian, secara keseluruhan variabel quality work life mendapatkan rerata yang masuk kategori tinggi dengan nilai 3.73.

Tabel 3 Distribusi frekuensi variabel quality work life $(\mathrm{X})$

\begin{tabular}{|c|c|c|c|c|c|c|c|c|c|c|c|}
\hline \multirow{2}{*}{ Indikator } & \multicolumn{2}{|c|}{ STS } & \multicolumn{2}{|c|}{ TS } & \multicolumn{2}{|c|}{$\mathbf{R}$} & \multicolumn{2}{|c|}{$\mathbf{S}$} & \multicolumn{2}{|c|}{ SS } & \multirow{2}{*}{ Rerata } \\
\hline & $\Sigma$ & $\%$ & $\Sigma$ & $\%$ & $\Sigma$ & $\%$ & $\Sigma$ & $\%$ & $\Sigma$ & $\%$ & \\
\hline \multicolumn{12}{|c|}{ Job and career satisfaction (kepuasan kerja dan karir) } \\
\hline $\begin{array}{l}\text { Saya diberi kesempatan dalam } \\
\text { mengembangkan karir dalam pekerjaan saya }\end{array}$ & 0 & 0 & 0 & 0 & 2 & 6 & 28 & 80 & 5 & 14 & 4.09 \\
\hline $\begin{array}{l}\text { Saya termotivasi untuk meningkatkan } \\
\text { kemampuan saya }\end{array}$ & 0 & 0 & 0 & 0 & 1 & 3 & 29 & 83 & 5 & 14 & 4.11 \\
\hline \multicolumn{11}{|c|}{ Rerata indikator job and career satisfaction } & 4.10 \\
\hline \multicolumn{12}{|l|}{ Control at work (kontrol dalam pekerjaan) } \\
\hline $\begin{array}{l}\text { Saya diberi kesempatan dalam } \\
\text { menyampaikan pendapat dalam pekerjaan } \\
\text { saya }\end{array}$ & 0 & 0 & 1 & 3 & 2 & 6 & 29 & 83 & 3 & 9 & 3.74 \\
\hline $\begin{array}{l}\text { Saya dilibatkan dalam pengambilan } \\
\text { keputusan dalam pekerjaan saya }\end{array}$ & 0 & 0 & 1 & 3 & 11 & 31 & 19 & 54 & 4 & 11 & 3.31 \\
\hline $\begin{array}{l}\text { Saya terlibat dalam pengambilan keputusan } \\
\text { yang berpengaruh terhadap orang lain di } \\
\text { lingkungan kerja saya }\end{array}$ & 0 & 0 & 3 & 9 & 16 & 46 & 15 & 43 & 1 & 3 & 3.40 \\
\hline \multicolumn{11}{|c|}{ Rerata indikator control at work } & 3.48 \\
\hline \multicolumn{12}{|c|}{ Home work interface (hubungan pekerjaan-rumah) } \\
\hline $\begin{array}{l}\text { Waktu bekerja saya sesuai dengan jadwal } \\
\text { rutinitas dirumah }\end{array}$ & 0 & 0 & 6 & 17 & 4 & 11 & 22 & 63 & 3 & 9 & 3.63 \\
\hline $\begin{array}{l}\text { Atasan saya mendukung waktu kerja yang } \\
\text { fleksibel }\end{array}$ & 0 & 0 & 0 & 0 & 7 & 20 & 27 & 77 & 1 & 3 & 3.83 \\
\hline \multicolumn{11}{|c|}{ Rerata indikator home work interface } & 3.73 \\
\hline \multicolumn{12}{|c|}{ General well-being (kesejahteraan secara umum) } \\
\hline $\begin{array}{l}\text { Saya merasa puas dengan kehidupan saya } \\
\text { saat ini }\end{array}$ & 0 & 0 & 1 & 3 & 7 & 20 & 23 & 66 & 4 & 11 & 3.86 \\
\hline \multirow[t]{2}{*}{$\begin{array}{l}\text { Saya merasa tidak nyaman dengan kondisi } \\
\text { dilingkungan kerja saya }(\mathrm{R})\end{array}$} & 5 & 14 & 19 & 54 & 10 & 29 & 1 & 3 & 0 & 0 & 3.80 \\
\hline & \multicolumn{10}{|c|}{ Rerata indikator general well-being } & $\mathbf{3 . 8 3}$ \\
\hline \multicolumn{12}{|l|}{ Stress at work (tekanan dalam pekerjaan) } \\
\hline \multirow[t]{2}{*}{ Saya merasa tertekan dalam bekerja $(\mathrm{R})$} & 6 & 17 & 20 & 57 & 8 & 23 & 1 & 3 & 0 & 0 & 3.89 \\
\hline & \multicolumn{10}{|c|}{ Rerata indikator stress at work } & 3.89 \\
\hline \multicolumn{12}{|l|}{ Working conditions (kondisi pekerjaan) (X6) } \\
\hline \multirow{3}{*}{$\begin{array}{l}\text { Saya merasa aman dalam bekerja } \\
\text { RS memberi fasilitas penunjang kerja yang } \\
\text { kondusif }\end{array}$} & 0 & 0 & 1 & 3 & 9 & 26 & 24 & 68 & 1 & 3 & 3.71 \\
\hline & 0 & 0 & 4 & 11 & 16 & 46 & 14 & 40 & 1 & 3 & 3.34 \\
\hline & & & \multicolumn{8}{|c|}{ Rerata indikator working conditions } & 3.53 \\
\hline Rerata variabel quality work life $(\mathbf{X})$ & & & & & & & & & & & 3.73 \\
\hline
\end{tabular}


Variabel employee engagement (Y1) terdiri dari indikator cognitive, emotional dan physical. Terdapat 10 item pernyataan yang diajukan kepada responden untuk dijawab. Hasil tabulasi distribusi frekuensi variabel employee engagement (Y1) disajikan pada tabel 4.

Tabel 4 menunjukkan pendapat responden pada aspek employee engagement perawat di RS Ananda. Secara keseluruhan pada variabel employee engagement (Y1), ada responden yang menyatakan setuju dan sangat setuju lebih dari $75 \%$ bahkan sampai $100 \%$ pada tiga item, yaitu responden merasa waktu berlalu dengan cepat saat bekerja (77\%), responden bekerja hingga benar-benar selesai $(85 \%)$ dan item responden mencintai pekerjaannya (100\%), namun demikian masih ada responden sebesar 78\% menyatakan bahwa mereka ragu-ragu dan tidak dapat larut dalam pekerjaannya
Indikator emotional engagement merupakan indikator yang mempunyai rerata tertinggi sebesar 3.75 (masuk dalam kategori tinggi) pada variabel employee engagement perawat Rumah Sakit Ananda. Sumbangan terbesar dari indikator emotional engagement adalah pada item responden mencintai pekerjaannya yaitu sebesar 4.26. Indikator physical engagement memiliki rerata tertinggi kedua dengan nilai 3,42 (masuk dalam kategori sedang). Rerata item tertinggi yaitu responden bekerja hingga pekerjaan benar-benar selesai dengan nilai 3,94. Indikator yang memiliki rerata terendah ditunjukkan oleh cognitive dengan nilai 3.35 (masuk dalam kategori sedang). Rerata terendah pada item responden larut saat melakukan pekerjaan hingga melupakan hal lain yaitu sebesar 2.69. Secara keseluruhan variabel employee engagement mendapatkan rerata yang masuk kategori sedang dengan nilai 3.47..

Tabel 4. Distribusi frekuaesi variabel employee engagement (Y1)

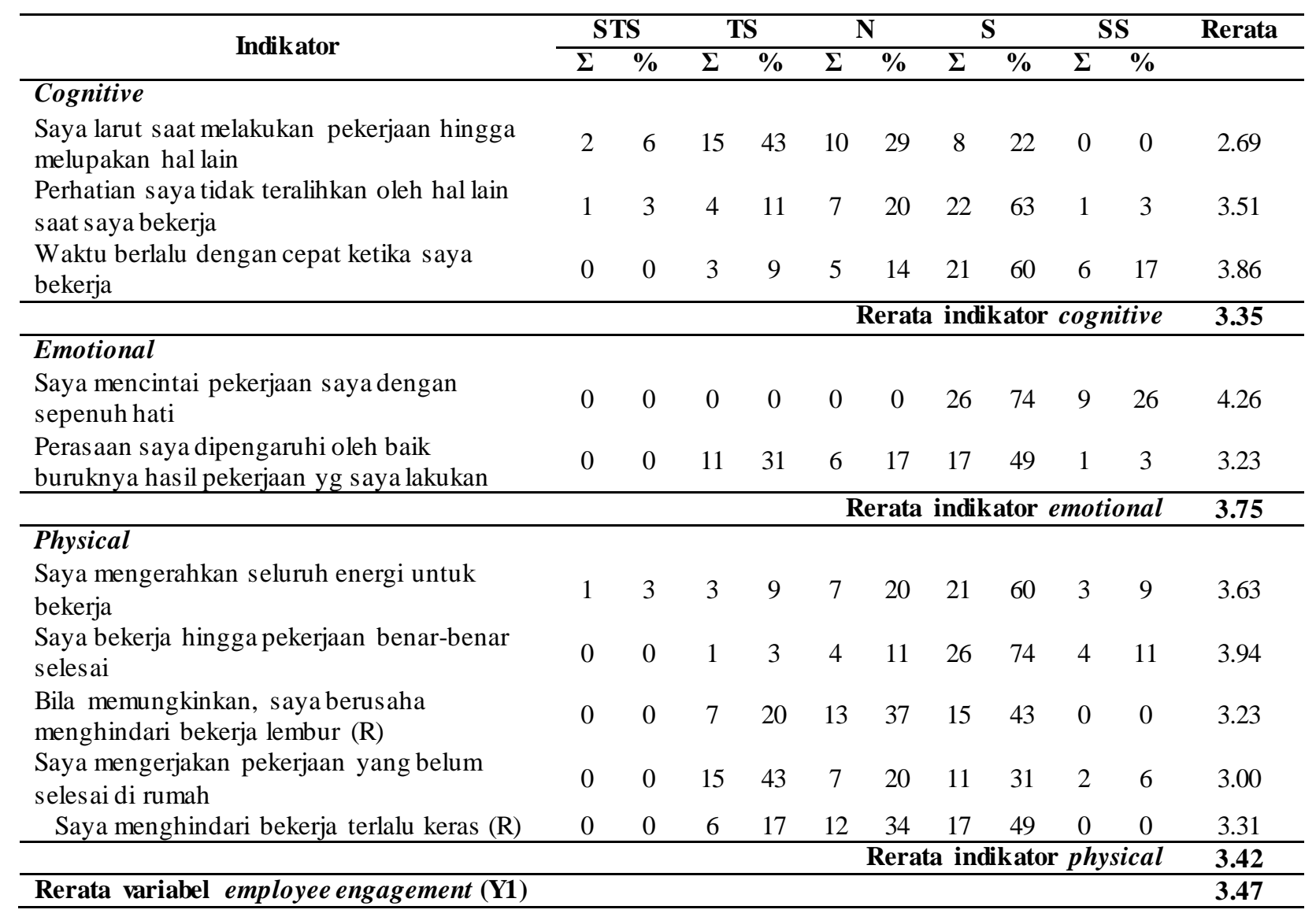


Tabel 5. Distribusi frekuensi variabel turnover intention (Y2)

\begin{tabular}{|c|c|c|c|c|c|c|c|c|c|c|c|}
\hline \multirow{2}{*}{ Indikator } & \multicolumn{2}{|c|}{ STS } & \multicolumn{2}{|c|}{ TS } & \multicolumn{2}{|c|}{$\mathbf{R}$} & \multicolumn{2}{|c|}{$\mathbf{S}$} & \multicolumn{2}{|c|}{ SS } & \multirow{2}{*}{ Rerata } \\
\hline & $\Sigma$ & $\%$ & $\Sigma$ & $\%$ & $\bar{\Sigma}$ & $\%$ & $\Sigma$ & $\%$ & $\Sigma$ & $\%$ & \\
\hline Keinginan untuk keluar dari pekerjaan & & & & & & & & & & & \\
\hline $\begin{array}{l}\text { Saya merasa kemampuan saya tidak } \\
\text { berkembang secara optimal saat bekerja di } \\
\text { RS ini (R) }\end{array}$ & 2 & 6 & 22 & 62 & 9 & 26 & 1 & 3 & 1 & 3 & 3.40 \\
\hline $\begin{array}{l}\text { Saya merasa bahwa keputusan berkerja di RS } \\
\text { ini adalah sebuah kesalahan }(\mathrm{R})\end{array}$ & 4 & 11 & 27 & 77 & 3 & 9 & 1 & 3 & 0 & 0 & 3.97 \\
\hline $\begin{array}{l}\text { Saya tidak ingin terlalu lama bekerja di RS } \\
\text { ini (R) }\end{array}$ & 1 & 3 & 26 & 74 & 8 & 23 & 0 & 0 & 0 & 0 & 3.80 \\
\hline Keinginan untuk keluar dari pekerjaan & & & & & & & & & & & \\
\hline $\begin{array}{l}\text { Saya mencari informasi lowongan kerja di } \\
\text { RS lain (R) }\end{array}$ & 0 & 0 & 27 & 77 & 8 & 23 & 0 & 0 & 0 & 0 & 3.77 \\
\hline $\begin{array}{l}\text { Jika ada kesempatan bekerja ditempat yg } \\
\text { lebih baik, saya akan pindah kerja }(\mathrm{R})\end{array}$ & 0 & 0 & 17 & 49 & 14 & 40 & 4 & 11 & 0 & 0 & 3.03 \\
\hline Rerata variabel turnover intention (Y2) & & & & & & & & & & & 3.59 \\
\hline
\end{tabular}

Jawaban responden menunjukkan bahwa mereka mempunyai emotional engagement yang tinggi dan cognitive serta physical engagement yang termasuk pada kategori sedang Variabel turnover intention (Y2) mempunyai 5 item pernyataan yang diajukan kepada responden untuk dijawab. Hasil tabulasi distribusi frekuensi variabel turnover intention (Y2) disajikan pada Tabel 5.

Tabel 5 menunjukkan pendapat responden pada aspek keinginan keluar perawat di RS Ananda. Sebagian besar responden menyatakan ragu-ragu hingga sangat tidak setuju dengan persentase lebih dari $85 \%$ pada seluruh pernyataan ingin

keluar dari pekerjaan (variabel turnover intention), namun demikian masih ada beberapa responden $(11 \%)$ yang menyatakan bahwa responden akan pindah bekerja jika ada tempat yang lebih baik, sebagian kecil respoden merasa kemampuannya tidak berkembang dengan optimal (6\%) dan ada sedikit responden (3\%) yang menyatakan bahwa bekerja di Rumah Sakit Ananda adalah keputusan yang salah. Secara keseluruhan variabel turnover intention masuk kategori sedang dengan nilai rerata sebesar 3.59.

\section{Pembahasan}

\section{Quality Work Life Di Rumah Sakit Ananda}

Rumah Sakit Ananda salah satu rumah sakit swasta di Jawa Timur, yang mengalami angka turnover yang cukup tinggi. Dalam laporan tahunan pada empat tahun terakhir angka turnover mengalami fluktuasi. Hasil wawancara tidak terstruktur yang dilakukan saat studi pendahuluan pada beberapa perawat dan staf di Rumah Sakit Ananda menunjukkan bahwa alasan perawat keluar disebabkan antara lain adalah karena ketidakpuasan perawat terhadap pendapatan yang diterima, tingginya beban kerja perawat dan beberapa perawat diterima sebagai pegawai negeri sipil (PNS). Sementara itu, perpindahan perawat menjadi PNS di rumah sakit pemerintah dapat diartikan bahwa perawat Rumah Sakit Ananda masih mencari tempat kerja yang memberikan job security yang kuat, selain budaya di Indonesia bahwa menjadi PNS menunjukan kebanggaan [9]. Job insecurity merupakan salah satu penyebab intention to leave [10]

Quality work life di Rumah Sakit Ananda termasuk dalam kategori tinggi. Jika dilihat dari enam indikator yang terdiri dari job and career satisfaction (kepuasan kerja dan karir), control at work (kontrol dalam pekerjaan), home work interface (hubungan pekerjaan-keluarga), general well-being (kesejahteraan secara umum), stress at work (tekanan dalam pekerjaan) 
dan working conditions (kondisi pekerjaan) maka indikator yang memiliki rerata tertinggi adalah job and career satisfaction (kepuasan kerja dan karir). Item kesempatan responden dalam pengembangan karir dan responden termotivasi untuk meningkatkan kemampuannya memiliki rerata tertinggi yang hampir sama, hal ini dapat dikatakan bahwa perawat termotivasi bekerja di Rumah Sakit Ananda dan merasa dapat meningkatkan jenjang karirnya.

\section{Pengaruh Langsung Quality Work Life Terhadap Employee Engagement}

Hasil penelitian menunjukan bahwa terdapat kesesuaian dengan hipotesis penelitian ini yang menyatakan bahwa quality work life berpengaruh langsung terhadap employee engagement. Hasil uji hipotesis membuktikan bahwa quality work life mempengaruhi employee engagement secara signifikan sehingga hipotesis pertama dalam penelitian ini diterima. Koefisien jalur yang diperoleh bertanda positif, menunjukan bahwa quality work life memberikan pengaruh positif terhadap employee engagement, yang artinya semakin tinggi quality work life, maka employee engagement akan semakin kuat, atau sebaliknya semakin rendah quality work life, maka employee engagement akan semakin lemah.

Hasil penelitian ini mendukung penelitian terdahulu yang dilakukan oleh [28] yang menyatakan bahwa quality work life (QWL) berpengaruh secara signifikan terhadap employee engagement. Dalam penelitiannya di Turki disimpulkan bahwa terdapat hubungan yang signifikan antara quality work life terhadap work engagement dan terdapat perbedaan persepsi antara karyawan pada level atas dan bawah terhadap quality work life serta terdapat perbedaan tingkat work engagement pada karyawan level atas dengan karyawan level bawah. Pada penelitian ini tidak membedakan golongan atau level perawat.
Studi yang lain [30] menunjukkan bahwa quality work life berpengaruh terhadap employee engagement, studi ini menggunakan instrumen quality work life dan employee engagement yang berbeda. Studi [30] ini sesuai dengan hasil studi [31] yang menyatakan bahwa memperkuat kepemimpinan dapat menciptakan lingkungan kerja yang berkualitas (quality work life) sehingga dapat meningkatkan keterikatan karyawan terhadap pekerjaannya dan menurunkan burnout. Burnout merupakan salah satu media pemicu munculnya turnover [32].

Hasil R Square pada penelitian ini menunjukan bahwa quality work life mempengaruhi employee engagement sebesar $21.4 \%$, sedangkan sisanya sebesar $78.6 \%$ dipengaruhi oleh variabel lain diluar variabel bebas yang diteliti, hal ini menunjukan bahwa ada faktor luar selain quality work life [14] yang memberikan pengaruh cukup besar terhadap employee engagement, namun faktor tersebut tidak diteliti pada penelitian ini. Faktor lain yang tidak diteliti tersebut antara lain terdapat pada studi tentang quality work life oleh [34] dan [35] yang menyatakan bahwa employee engagement dipengaruhi oleh quality work life yang terdiri dari dimensi leadership, empowerment dan image, sedangkan equal opportunities dan fair treatment, performance appraisal, pay dan benefits, health dan safety, communication serta co-operation merupakan dimensi dari quality work life yang dikemukakan oleh [36].

\section{Pengaruh Langsung Employee Engagement Terhadap Turnover Intention}

Hasil penelitian didapatkan bahwa employee engagment perawat Rumah Sakit Ananda termasuk dalam kategori tinggi, dan turnover intention perawat di Rumah Sakit Ananda dalam kategori sedang. Hipotesis kedua penelitian ini menyatakan bahwa employee engagment berpengaruh langsung terhadap turnover intention perawat. Hasil uji hipotesis membuktikan 
bahwa employee engagment mempengaruhi turnover intention perawat secara signifikan sehingga hipotesis kedua dalam penelitian ini diterima.

Koefisien jalur yang diperoleh bertanda positif hasil reversed, menunjukan bahwa employee engagment memberikan pengaruh dengan arah berkebalikan terhadap turnover intention perawat, yang artinya semakin kuat employee engagment, maka turnover intention perawat akan semakin rendah, begitu juga sebaliknya semakin lemah employee engagement, maka turnover intention perawat akan semakin tinggi.

Hasil ini sesuai dengan penelitian terdahulu yang dilakukan oleh [20]. [20] menyatakan bahwa employee engagement dapat menekan keinginan karyawan untuk keluar dari tempat kerjanya. Hal yang senada dinyatakan oleh [21] yang menyatakan bahwa semakin tinggi employee engagement maka akan menurunkan turnover karyawan. Pernyataan [21] sejalan dengan [37] yang menyatakan bahwa pekerja yang mempunyai rasa keterikatan yang kuat terhadap organisasi tempat ia bekerja berarti mempunyai dan membentuk perasaan memiliki (sense of belonging), rasa aman, efikasi, tujuan dan arti hidup, serta gambaran diri yang positif. Hal ini akan berakibat secara langsung menurunnya dorongan diri untuk berpindah pekerjaan atau organisasi. Lebih jauh, [38] menyatakan organisasi dengan employee engagement tinggi akan mengurangi pengeluaran karena sedikitnya karyawan yang meninggalkan organisasi yang berarti mengurangi biaya rekrutmen dan biaya pelatihan.

Hasil penelitian ini juga sesuai dengan penelitian [22], yang menyatakan bahwa semakin tinggi tingkat employee engagement maka akan menurunkan kecenderungan untuk meninggalkan organisasi (turnover intention). Keterlibatan karyawan yang besar pada organisasi dan memiliki pengalaman yang positif, yang mengarah ke kecenderungan lebih rendah untuk meninggalkan organisasi [39] dan [40].

\section{Pengaruh Langsung Quality Work Life Terhadap Turnover Intention}

Hasil penelitian didapatkan bahwa quality work life perawat termasuk dalam kategori tinggi, dan turnover intention pearawat di Rumah Sakit Ananda dalam kategori sedang. Hipotesis ketiga penelitian ini menyatakan bahwa quality work life berpengaruh langsung terhadap turnover intention perawat. Hasil uji hipotesis membuktikan bahwa quality work life mempengaruhi turnover intention perawat secara signifikan sehingga hipotesis ketiga dalam penelitian ini diterima.

Koefisien jalur bertanda positif hasil reversed, menunjukan bahwa quality work life memberikan pengaruh dengan arah negatif terhadap turnover intention perawat, yang berarti bahwa semakin tinggi quality work life maka turnover intention perawat semakin rendah, begitu juga sebaliknya semakin rendah quality work life, maka turnover intention perawat semakin tinggi.

Hasil penelitian ini mendukung penelitian terdahulu yang dilakukan oleh [13], quality work life yang tinggi dapat meningkatkan keterikatan perawat terhadap pekerjaan dan komitmen mereka, hal itu meningkatkan loyalitas perawat terhadap organisasinya hingga dapat menurunkan niat untuk mengundurkan diri (turnover intention). Dalam penelitiannya pada perawat yang bertugas full-time di China menyatakan bahwa terdapat hubungan yang signifikan dan berkorelasi negatif sehingga semakin tinggi tingkat quality work life maka akan semakin rendah niat untuk mengundurkan diri dan juga sebaliknya. Pada penelitian ini menggunakan perawat dengan sistim shif.

Hal yang senada dinyatakan oleh [19] pada penelitiannya terhadap 1.283 perawat pada tujuh rumah sakit di Taiwan dengan menggunakan Chinese-Quality of 
nursing work scale (C-QNWL) sebagai alat ukurnya menyatakan bahwa terdapat hubungan yang signifikan bernilai negatif antara quality work life terhadap turnover intention, sehingga semakin quality work life maka semakin tinggi niat untuk meninggalkan pekerjaan.

Pada penelitian lain, [18] dalam penelitiannya pada 508 perawat layanan primer di wilayah Jazan Saudi Arabia dengan Anticipated Turnover Scale (ATS) dan The Brooks' survey of Quality Nursing Work life (QNWL) sebagai instrumen pengukuran, menyatakan bahwa terdapat hubungan signifikan bernilai negatif antara quality work life terhadap turnover intention, yang mengindikasikan bahwa semakin rendah kepuasan perawat terhadap quality work life maka semakin tinggi turnover intention. Sementara itu [17] juga menyatakan dalam penelitiannya pada 326 auditor bahwa terdapat hubungan negatif antara quality work life terhadap turnover intention, artinya bahwa quality work life yang baik dapat menekan turnover intention.

Pengaruh Tidak Langsung Quality Work Life Terhadap Turnover Intention Melalui Employee Engagement

Hipotesis keempat dari penelitian ini menyatakan bahwa quality work life berpengaruh secara tidak langsung terhadap turnover intention perawat melalui employee engagement. Hasil uji hipotesis menunjukan hubungan quality work life secara tidak langsung terhadap turnover intention perawat melalui employee engagement, sehingga hipotesis keempat dalam penelitian ini diterima.

Hasil uji analisis jalur peran mediasi employee engagement pada pengaruh quality work life terhadap turnover intention perawat, menemukan adanya jalur pengaruh tidak langsung. Hasil uji analisis jalur menemukan adanya jalur pengaruh total quality work life terhadap turnover intention perawat. Pengaruh tidak langsung antara quality work life terhadap turnover intention perawat melalui employee engagement dapat diartikan bahwa peningkatan quality work life dapat meningkatkan employee engagement dan selanjutnya employee engagement dapat menurunkan turnover intention di Rumah Sakit Ananda.

Hasil R Square pada penelitian ini menunjukan bahwa quality work life dan employee engagement mempengaruhi turnover intention sebesar $43.6 \%$ sedangkan ada faktor lain sebesar $56.4 \%$ yang mempengaruhi turnover intention diluar dari variabel yang diteliti. Faktor lain tersebut dapat dijelaskan dengan konsep [37] yang menyatakan bahwa turnover intention tidak hanya dipengaruhi oleh quality work life tetapi juga dipengaruhi oleh socio-demographics characteristics, organizational characteristics, social support at home, social support at work dan job tension. Namun faktor-faktor tersebut tidak diteliti pada penelitian ini.

Pengaruh tidak langsung antara quality work life terhadap turnover intention melalui employee engagement mempunyai hasil yang signifikan walaupun lebih kecil bila dibandingkan dengan pengaruh langsung quality work life terhadap turnover intention perawat. Hal ini dapat diartikan bahwa peningkatan quality work life dapat mamperkuat employee engagement dan selanjutnya employee engagement menurunkan turnover intention perawat di Rumah Sakit Ananda.

\section{KESIMPULAN}

Berdasarkan hasil analisis dan pembahasan diketahui bahwa persepsi perawat terhadap quality work life di Rumah Sakit Ananda berada pada kategori tinggi, sedangkan employee engagement dan turnover intention termasuk dalam kategori sedang. Quality work life perawat Rumah Sakit Ananda bernilai tinggi mempengaruhi employee engagement bernilai sedang. Employee engagement 
bernilai sedang mempengaruhi turnover intention perawat bernilai sedang. Quality work life perawat Rumah Sakit Ananda tinggi mempengaruhi turnover intention perawat bernilai sedang. Quality work life secara tidak langsung mempengaruhi turnover intention perawat Rumah Sakit Ananda melalui employee engagement.

\section{DAFTAR PUSTAKA}

[1] AONE, 2000. Nurse Executive Competencies: Assessment Tool. American Organization of Nurse Executives.

[2] World Health Organization, 2004. Human resources in health: Report by the secretariat. Executive Board, EB 114/17, 114th Session, 29th April. Geneva: WHO.

[3] Buchan, J., \& Calman, L, 2005. The global shortage of nurses: An overview of the issues and actions, Geneva: Switzerland: The International Council of Nurses.

[4] Badan PPSDM Kesehatan, 2019. Departemen Kesehatan Nasional RI. Jakarta.

[5] Tobing. 2009. Pengaruh Komitmen Organisasional dan Kepuasan Kerja Terhadap Kinerja Karyawan PT. Perkebunan Nusantara III di Sumatera Utara. Jurnal Manajemen Dan Kewirausahaan, 11(1), 31-37.

[6] Hayati, 2007. Turnover tenaga perawat di Rumah Sakit Harapan Bunda Batam. Jurnal Ilmu Kesehatan Masyarakat, UGM.

[7] RS Wava Husada, 2014. Laporan Tahunan Rumah Sakit Wava Husada 2014

[8] Gillies D.A, 2007. Nursing Management a System Approach. $3 \mathrm{Th}$ Editian. International Edition, WB Saunder.

[9] Mahsun. 2005. Manajemen Sumber Daya Manusia. Jakarta; Gunung Agung.

[10] Schalkwyk et al., 2010. Job insecurity, leadership empowerment, employee engagement and intention to leave in a Petrochemical Laboratory. SA Journal of Human Resource Management; vol 8, no.1, 7 pages.

[11]Harnoto, 2002. Manajemen Sumber Daya Manusia, Jakarta: Prehallindo.

[12] Andini, 2006. Analisis pengaruh kepuasan gaji, kepuasan kerja, komitmen organisasional terhadap turnover intention (Studi Kasus di Rumah Sakit Roemani Muhammadiyah Semarang), Program Pascasarjana Universitas Diponegoro.

[13]Zhao et al., 2012. "The impact of quality of work life on job embeddedness and affective commitment and their co-effect on turnover intention of nurses." Journal of clinical nursing 22.5-6: 780-788.

[14] Van Laar et al., 2007. The work related quality of work life scale for healthcare workers. Journal of Advanced Nursing 60, (3): 325-333.

[15] Sirgy et al., 2001. A new measure of quality of work life (QoWL) based on need satisfactionand spillover theories. Social Indicators Research, 55, 241-302.

[16]Fitri, N. Ulfa, 2013. Intensi untuk keluar pada perawat $\mathrm{RSH}$ dilihat dari Quality of working life, kepuasan kerja dan kelelahan emosi dengan kontrol kepuasan penghasilan, UGM.

[17]Huang et al., 2007. The effects of quality work life on commitment and turnover intention. Social behavior and personality,35 (6), 735-750.

[18] Almalki et al., 2012. The relationship between quality of work life and turnover intention of primary health care nurses in Saudi Arabia. BMC Health Services Research 2012, 12:314

[19]Lee et al., 2013. Predicting quality of work life on nuses' intention to leave. Journal of nursing scholarship; 45:2, 160-168.

[20]Ang et al., 2013. The effects of highperformance work systems on hospital 
employees' work attitudes and intention to leave: a multi-level and occupational group analysis, The international journal of human resource management, Vol. 24, no. 16, 3086-3114.

[21]Putri, Annisa, 2013. Pengaruh Employee Engagement Terhadap Turnover Karyawan Organisasi XYZ. Departemen Manajemen Fakultas Ekonomi dan Manajemen Institut Pertanian Bogor.

[22] Takawira et al., 2014. Job embeddedness, work engagement and turnover intention of staff in a higher education institution: An exploratory study. SA Journal of human Resource Management, 12(1).

[23]Kahn, W. A, 1990. "Psychological conditions of personal engagement and disengagement at work." Academy of management journal 33.4: 692-724.

[24] Rich et. al., 2010. Job engagement: Antecedents and effects on job performance. Academy of Management Journal, 53, 617-635.

[25] Schaufeli \& Salanova. 2011. Work engagement: On how to better catch a slippery conceps. European journal of work and organizational psychology, 20, 39-46.

[26] Kahn, W. A, 1992. To be fully there: Psychological presence at work. Human Relations, 45, 321-349.

[27] Schaufeli et al., 2002. The measurement of engagement and burnout: A two sample confirmatory factor analytic approach. Journal of happiness studies, 3, 71-92.

[28] Kanten and Sadullah, 2012. An empirical research on relationship quality of work life and work engagement. Social and Behavioral Sciences 62: 360-366.

[29] Notoatmodjo, 2012. Metode penelitian kesehatan edisi revisi, Rineka Cipta, Jakarta.
[30] Greco et al., 2006. Leader empowering behaviours, staff nurse empowerment and work engagement/burnout. Nursing research. Vol 19 (4).

[31] Maslach, C., Schaufeli, W.B. \& Leiter, M.P, 2001. Job burnout. Annual Review of Psychology, 52, 397-422.

[32]Leiter, Michael P., and Christina Maslach. 2009. "Nurse turnover: the mediating role of burnout." Journal of nursing management 17.3: 331-339.

[33] Robinson D, Perryman, S. \& Hayday, S., 2004. The drivers of employee engagement. Institute for employee studies, Brighton, report 408, retrieved on Desember $14^{\text {th }}, 2011$.

[34] Robinson D, Perryman, S. \& Hayday, S., 2004. The drivers of employee engagement. Institute for employee studies, Brighton, report 408, retrieved on Desember $14^{\text {th }}, 2011$.

[35]Kumar, J.A, 2012. Employee engagement, Saaransh, RKG Journal of Management, 3(2).

[36] Funnell R, 2010. Quality of working life in Victoria's public hospitals. School of nursing and midwifery, faculty of health, engineering and science, Victoria University, Australia.

[37] Mobley et al., 1982. An evaluation of precursors of hospital employee turnover. Journal of applied psychology 64 (4), 408-414.

[38]Kruse, K, E. 2012. Employee Engagement 2.0: How to Motivate Your Team for High Performance.

[39] Saks. Alan M, 2006. Antecedents and Consequences of Employe engagement. Journal of Managerial Psychology. Vol. 21 Iss:7 pp. 600-619

[40] Schaufeli, W.B., Bakker, A.B. \& Salanova, M. 2006. The measurement of work engagement with a short questionnaire: A cross-national study. Educational and Psychological Measurement, 66, 701-716 